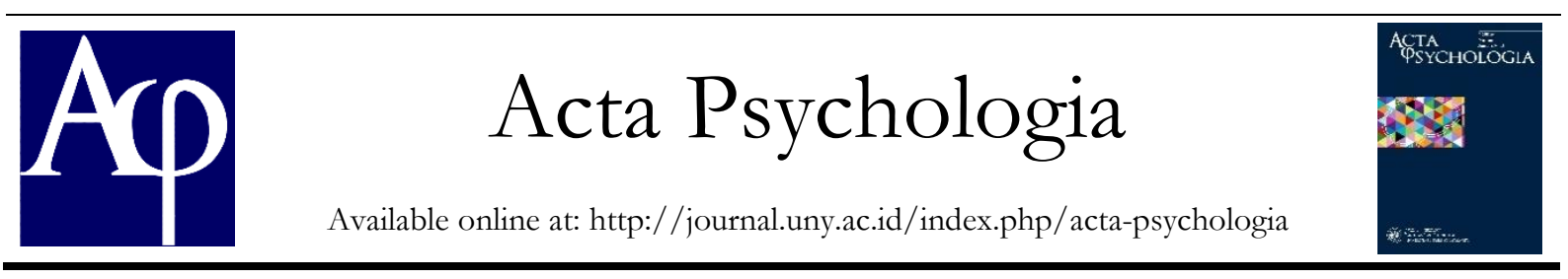

\title{
Dinamika Psikologis Pelaku Dance Cover Lintas Gender
}

\author{
Koeswidiana Jati Permana \\ Jurusan Psikologi, Fakultas Ilmu Pendidikan, Universitas Negeri Yogyakarta; \\ Jl. Colombo No. 1 Sleman Yogyakarta, 55281 \\ jatipermana62@gmail.com
}

\begin{abstract}
Abstrak
Fenomena lintas gender yang muncul di komunitas dance cover menimbulkan berbagai macam pandangan dan pemahaman. Penelitian ini bertujuan untuk mengetahui alasan pelaku menampilkan lintas gender, pandangan pelaku dance cover terhadap fenomena lintas gender, dan cara pelaku menanggapi respon dan opini dari kelompok masyarakat. Penelitian ini menggunakan metode kualitatif dengan pendekatan fenomenologis. Penelitian ini dilakukan di Yogyakarta. Subjek penelitian terdiri dari 4 responden dengan rincian 2 pria menampilkan tarian wanita dan 2 wanita yang menampilkan tarian pria. Teknik pengambilan data yang digunakan adalah wawancara mendalam yang dianalisis menggunakan teknik Interpretative Phenomenological Analysis (IPA). Hasil penelitian ini menemukan latar belakang pelaku dance cover melakukan penampilan lintas gender. Alasan yang ditemukan yaitu karena motivasi intrinsik seperti mencari identitas dan relasi afiliasi. Adapun motivasi ekstrinsik yaitu karena pengaruh dan penerimaan dari teman sebaya (peer acceptance).
\end{abstract}

Kata Kunci: lintas gender, dance cover, motivasi

\begin{abstract}
The cross-gender phenomenon that appears in the dance cover community creates various viewpoints and comprehensions. This study aims to determine the reasons for dancer to perform across genders dance, the views of cover dancer towards cross-gender phenomena, and how dancer respond to responses and opinions from community groups. This study used a qualitative method with a phenomenological approach. This study was conducted in Yogyakarta. There were 4 respondents with details of 2 men who performed female dances and 2 women who performed male dances. The data collection technique used was in-depth interviews which were analyzed using the Interpretative Phenomenological Analysis (IPA) technique. This study found the reasons for the perpetrators to perform across genders, namely intrinsic motivation such as looking for identities and affiliations and extrinsic motivation, which is peer acceptance.
\end{abstract}

Keywords: cross gender, dance cover, motivation

\section{Pendahuluan}

Komunitas dance cover yang banyak berkembang beberapa waktu belakangan, banyak dipengaruhi oleh budaya Korea yang masuk ke Indonesia. Hal ini ditandai dengan tingginya animo peserta dan penonton setiap kali kegiatan seni budaya Korea, terutama kegiatan yang menampilkan dance cover. Indonesia pun sempat menjadi tuan rumah kompetisi dance cover tingkat ASEAN dan berhasil menarik banyak penonton dan peserta dari dalam hingga luar negeri (Pangerang, 2015). Khiun (2013) menyebut dance cover sebagai dance tracker atau pelacak tari adalah penggemar yang lebih mencari keterlibatan fisik dari dunia hiburan Korea. Penggemar K-pop memiliki tujuan untuk bisa mengamati dan mempraktikkan koreografi khas dari video musik tersebut dan berusaha mereplikasi serta menyempurnakan gaya dance grup favorit mereka. Sinkronisasi adalah tujuan yang harus dicapai dengan latihan yang lebih terkoordinasi. 
Dalam menampilkan suatu performance atau pertunjukan menari, tidak jarang terdapat penari lintas gender. Lintas gender dalam performance art menurut Didik Nini Thowok (dalam Fauzan, 2015) memiliki dua tipe, yaitu perempuan yang berperan sebagai laki-laki (female to male) dan laki-laki yang memerankan sebagai perempuan (male to female). Fenomena penari lintas gender menjadi menarik ketika diperhatikan demografi usia para penampilnya. Menurut teori perkembangan psikososial dari Erik Erikson, usia 10-20 tahun adalah saat individu mengeksplorasi dan menemukan identitas diri (Santrock, 2012). Identitas diri adalah sebuah istilah yang mencakup topik bahasan yang luas, di dalamnya termasuk identitas seksual dan identitas gender.

Identitas gender dalam pandangan kultur masyarakat Indonesia pada umumnya beranggapan bahwa seorang laki laki sudah sepatutnya berperilaku layaknya seorang laki-laki (maskulin) dan sebaliknya perempuan sudah sepatutnya berperilaku layaknya seorang perempuan (feminim), hal ini ditandai oleh adanya budaya patriarki yang juga identik dengan pandangan bahwa laki-laki merupakan makhluk yang lebih kuat, lebih berani, lebih bijak bahkan lebih pintar. Sementara itu, perempuan cenderung dipandang lebih rapuh, penakut, mudah terbawa perasaan dan tidak bisa mengambil keputusan dengan bijak (Pijarpsikologi, 2019).

Hal ini menyebabkan munculnya berbagai macam pandangan dan perilaku di masyarakat dalam menyikapi fenomena tari lintas gender. Terdapat kelompok masyarakat yang mendukung pertunjukan lintas gender ini. Seperti pada penelitian Sunardi (2009) yang menyatakan bahwa lintas gender telah menjadi praktik yang diterima yang merupakan bagian integral dari pandangan dunia lokal di Jawa Timur dan juga merupakan sub-versi konstruksi resmi kejantanan dan kewanitaan. Di Sumatra Barat, tepatnya di Kabupaten
Pasaman dan Kabupaten Pasaman Barat masih dapat ditemukan kesenian tradisi lintas gender bernama Ronggeang Pasaman yang masih diapresiasi oleh masyarakatnya hingga sekarang (Meigalia \& Putra, 2019).

Di sisi lain terdapat juga kelompok yang menentang fenomena lintas gender karena adanya kesalahan dalam membedakan lintas gender dan Lesbian Gay Biseksual Transgender (LGBT) sehingga menimbulkan konflik tersendiri. Seperti kasus pembubaran acara dance cover K-pop di salah satu Mall di Magelang pada 14 Oktober 2018 yang diberitakan oleh media Jawapos.com, polisi melakukan pembubaran kegiatan tersebut atas beredarnya isu adanya unsur LGBT yang disebarkan oleh salah satu ormas daerah setempat (Hardiyanto, 2018). Namun setelah dilakukan penyelidikan dengan memeriksa 13 orang saksi dari manajemen Mall, penyelenggara dan penonton, polisi menyimpulkan bahwa acara tersebut tidak mengandung unsur LGBT sebagaimana informasi yang beredar (Fitriana, 2018).

Dibalik pandangan yang berbedabeda tersebut, komunitas dance cover lintas gender masih tetap "eksis" menampilkan pertunjukannya. Narasumber dalam penelitian ini adalah Aldi seorang pelaku dance cover lintas gender selama 5 tahun terakhir berpandangan bahwa fenomena lintas gender dalam dance cover adalah hal wajar, karena dance cover adalah salah satu bentuk seni. Fenomena lintas gender menjadi menarik karena terdapat pandangan yang berbeda antara pelaku dance cover yang menampilkan lintas gender dengan masyarakat yang melihat fenomena tersebut.

Pelaku dance cover menganggap lintas gender merupakan hal yang wajar dalam dance cover karena itu merupakan bentuk ekspresi seni. Di sisi lain terdapat juga masyarakat yang tidak setuju dan memberikan persekusi verbal berupa omongan yang tidak menyenangkan 
terhadap mereka. Menurut teori law of effect dari Thorndike (dalam Moreno, 2010) hubungan stimulus respon cenderung diperkuat bila akibatnya menyenangkan dan cenderung diperlemah jika akibatnya tidak memuaskan. Sejalan dengan teori tersebut Reeves (2009) mengatakan bahwa orang yang menerima hukuman lebih kecil kemungkinannya untuk mengulangi perilaku tersebut dibandingkan dengan orang yang tidak menerima konsekuensi permusuhan karena melakukan hal yang sama.

Hal ini tidak sesuai dengan kondisi dimana pelaku dance cover lintas gender yang menerima persekusi verbal dari masyarakat seharusnya memperlemah perilaku dance lintas gender, namun sebaliknya pelaku justru tetap menjalankan aktivitasnya seakan tidak terpengaruh dengan komentar negatif. Persekusi verbal dari masyarakat berperan sebagai konsekuensi "punisher" bagi pelaku dance cover lintas gender, Punisher adalah stimulus semua stimulus lingkungan yang ketika disajikan akan mengurangi kemungkinan perilaku yang tidak diinginkan di masa depan. Kritik, hukuman penjara, dan ejekan publik beroperasi sebagai bentuk dari punisher (Revees, 2009).

Terdapatnya ketimpangan antara teori dan fakta membuat dinamika psikologis pelaku dance cover lintas gender penting untuk dikaji agar dapat memahami motivasi dan alasan pelaku melakukan dance lintas gender walaupun mendapat komentar negatif. Penelitian ini bertujuan untuk mengkaji lebih dalam mengenai alasan serta faktor lain yang mempengaruhi masih eksisnya pelaku dance cover lintas gender, dan cara pelaku lintas gender menanggapi respon masyarakat yang beragam. Hal tersebut menjadi alasan peneli kemudian melakukan penelitian berjudul Dinamika Psikologis Pelaku Dance Cover Lintas Gender.

\section{Metode Penelitian}

Jenis penelitian

Penelitian ini menggunakan pendekatan Kualitatif. Metode penelitian kualitif digunakan dengan alasan mampu mengeksplorasi fenomena dalam penelitian ini lebih dalam dan tepat karena penelitian kualitatif memiliki tujuan describe and explore. Pendekatan yang digunakan dalam penelitian ini adalah Interpretative Phenomenological Analysis (IPA). IPA merupakan pendekatan penelitian kualitatif yang dilakukan untuk menguji bagaimana orang memahami pengalaman hidup utama mereka

Pendekatan IPA tepat digunakan dalam penelitian ini karena peneliti tertarik untuk mengeksplorasi lebih jauh mengenai pengalaman hidup individu pelaku lintas gender dalam dance cover. Bagaimana suatu pengalaman penting dalam hidup individu dapat berpengaruh dan memunculkan fenomena yang saat ini terjadi dalam hidupnya (Smith, Flowers, dan Larkin. 2009)

\section{Waktu dan tempat penelitian}

Penelitian dilaksanakan pada bulan Juli-September 2020. Lokasi penelitian yaitu di Komunitas Dance cover Yogyakarta. Kota Yogyakarta dipilih karena terdapat banyak komunitas dance cover sehingga akan memudahkan peneliti untuk menemukan responden yang masuk dalam kriteria atau karakteristik penelitian.

\section{Subjek penelitian}

Karakteristik subjek yang diteliti yaitu: (1) pria atau wanita berusia lebih dari 18 tahun, (2) tergabung kedalam komunitas Dance cover di kota Yogyakarta, (3) dalam setiap penampilannya membawakan karakter gender yang berlawanan dengan jenis kelaminnya. Responden dalam penelitian ini berjumlah 4 orang dengan rincian 2 orang pria dan 2 orang wanita. 
Prosedur

Penelitian dilakukan dengan
membuat janji wawancara dengan responden. Peneliti juga mengirimkan kuesioner online berisi pertanyaan serupa dengan wawancara guna untuk mengetahui validitas jawaban responden. Setelah selesai melakukan tahap wawancara dan responden telah mengisi kuesioner online, peneliti menuliskan transkrip wawancara dan membuat tema-tema penting serta koding untuk memetakan jawaban responden menjadi sebuah bentuk data

\section{Teknik pengumpulan data dan instrumen}

Pada penelitian ini digunakan teknik pengumpulan data berupa wawancara mendalam. Wawancara merupakan suatu proses interaksi dan komunikasi verbal dengan tujuan mendapatkan informasi yang diinginkan. Teknik wawancara semitersrtuktur digunakan karena dapat memungkinkan peneliti untuk memberikan pertanyaan tambahan diluar panduan wawancara guna menggali informasi lebih dalam dan atau mengkonfirmasi jawaban dari responden. Teknik wawancara semiterstruktur dapat mengurangi tekanan selama wawancara (Stewart \& Cash, 2012).

Instrumen dalam penelitian ini adalah peneliti sendiri karena peneliti merupakan buman interest yang berarti dapat menetapkan fokus penelitian, memilih informan sebagai sumber data, melakukan pengumpulan data, menilai kualitas data, analisis data, menafsirkan data, dan membuat kesimpulan atas temuannya (Sugiyono, 2016). Selain itu juga dilakukan berdasarkan Pedoman Wawancara. Pedoman wawancara digunakan sebagai alat instrumen pengumpulan data yang dibuat berdasarkan pertanyaan penelitian guna untuk menjawab tujuan penelitian.

\section{Teknik Analisis data}

Teknik analisis yang digunakan adalah teknik analisis Interpretative Phenomenological Analysis yang dilaksanakan dengan enam tahapan yaitu sebagai berikut: 1) Reading and re-reading; 2) Initial noting; 3) Developing emergent themes; 4) Searching for connections a cross emergent themes; 5) Moving the next cases; dan 6) Looking for patterns a cross cases (Smith, Flowers, dan Larkin, 2009).

\section{Hasil Penelitian dan Pembahasan}

Hasil penelitian menemukan terdapat aspek motivasi yang mendasari alasan individu melakukan dance cover lintas gender, yaitu aspek kompetensi, autonomi, keterkaitan atau afiliasi, achievement atau pencapaian, dan kebutuhan akan rasa aman. Aspek-aspek tersebut tersebar pada responden penelitian dan tidak semua aspek muncul pada satu individu. Setiap individu memiliki aspek yang berbeda-beda. Motivasi merupakan sebuah dasar penting dalam kinerja seseorang untuk memberikan dorongan kepada seseorang agar dapat bergerak mencapai tujuannya (Yunengsih, 2018).

Beradasarkan aspek-aspek motivasi tersebut dapat dibedakan alasan pelaku dance cover lintas gender berdasarkan arah motivasi, yaitu motivasi intrinsik dan motivasi ekstrinsik. Aspek autonomi, kompetensi dan kebutuhan akan rasa aman merupakan motivasi intrinsik yang berasal dari dalam diri individu. Subjek mulai mengenali K-POP dan dance cover lintas gender sejak masa remaja. Menurut teori perkembangan psikososial Erickson pada masa remaja individu dituntut untuk dapat mencari identitas sehingga menjadi pribadi yang unik dengan rasa diri yang koheren, dan memiliki nilai peran dalam kelompok sosial (Papalia \& Feldman, 2014).

Salah satu bentuk pencarian identitas adalah self-discovery. Terdapat halhal baru yang berubah ketika individu mengetahui K-POP dance cover. Penemuanpenemuan baru dalam dirinya inilah yang memunculkan alasan-alasan di atas sebagai bentuk dari self-discovery. Individu yang mengalami proses self-discovery adalah penanda atau membantu mendorong fungsi 
psikologis yang positif karena penemuan diri dapat memiliki peran penting yang digunakan untuk menemukan bukti bahwa individu adalah orang yang sama dari waktu ke waktu, terlepas dari perubahan yang mereka lihat dalam diri mereka sendiri (Bench dkk, 2015).

Bergabung dengan kelompok memiliki fungsi sebagai sumber identitas, sehingga mengikuti komunitas dance cover lintas gender membuat individu mampu mendefinisikan dan mengenali dirinya sebagai anggota suatu kelompok serta bertingkah laku sebagaimana norma kelompok tersebut (Sarwono \& Meinarno, 2009). Selanjutnya aspek Achievement dan keterkaitan/Afiliasi merupakan bentuk motivasi ekstrinsik individu dalam melakukan performa dance cover lintas gender. Menilik teori perkembangan psikososial Erickson, di masa dewasa awal tugas utama individu adalah untuk membentuk hubungan yang kuat, stabil, dekat, dan saling mengasihi, individu dapat menjadi intim (dekat) lewat sikap saling terbuka, responsif akan kebutuhan satu sama lain dan saling menerima serta menghargai (Papalia \& Feldman, 2014).

Mengikuti komunitas K-POP dance cover lintas gender adalah salah satu bentuk mencari teman dalam rangka membentuk suatu persahabatan. Individu yang memiliki banyak teman cenderung mempunyai kepekaan akan kesejahteraan orang lain, dan membuat individu merasa nyaman akan dirinya sendiri atau individu yang merasa nyaman dengan dirinya sendiri akan lebih mudah berteman (Papalia \& Feldman, 2014). Lingkungan komunitas dance cover lintas gender juga dapat memotivasi individu dalam melakukan aktifitasnya. Kelompok ingrup memberikan manfaat resiprokal atau efek timbal balik kepada individu (Sarwono \& Meinarno, 2009).

Pelaku memandang fenomena lintas gender dalam dance cover merupakan suatu bentuk seni yang universal, ditujukan untuk menghibur dan tidak untuk mengganggu orang lain serta sebagai sarana untuk menyalurkan minat dan bakan individu dalam menari, bergabung dengan komunitas dance cover lintas gender adalah bentuk aktualisasi diri sebagai sarana menuangkan diri kapasitas setiap individu sebagai manusia dengan tujuan untuk mewujudkan dan mengembangkan semua potensi serta bakat yang sesuai dengan kemampuan, minat dan bidangnya masingmasing (Purwanta, 2015).

Responden wanita mengungkapkan penggunaan atribut lintas gender dalam penampilannya meningkatkan rasa percaya diri karena merasa aman dan nyaman mengenakan pakaian yang tertutup dibandingkan kostum idol grup wanita yang lebih terbuka. Sementara itu, responden laki-laki mengungkapkan menjadi terbiasa menggunakan atribut lintas gender di luar kebutuhan untuk perform.

Adapun respon pelaku terhadap komentar tidak menyenangkan dari masyarakat yaitu melakukan pengurangan interaksi dengan individu yang bersangkutan serta tidak memperdulikan komentar-komentar tersebut. Hal ini dapat terjadi karena pelaku mengalami disonansi kognitif dimana terdapat perbedaan belief antara pelaku dance cover lintas gender dengan masyarakat yang tidak setuju menimbulkan kebingunan dan perasaan tidak nyaman pada diri individu. Disonansi dapat dikurangi dengan salah satu dari tiga cara yaitu mengubah belief yang ada, menambahkan belief baru, atau mengurangi pentingnya belief tersebut (McLeod, 2018), serta penghindaran disonansi (Joni \& Sutarmanto, 2017), sehingga respon tidak peduli dan menghindari interaksi muncul untuk menghilangkan kebingungan serta mengurangi perasaan tidak nyaman. Bagan dinamika psikologis pelaku dance cover lintas gender dapat dilihat pada Gambar 1. 


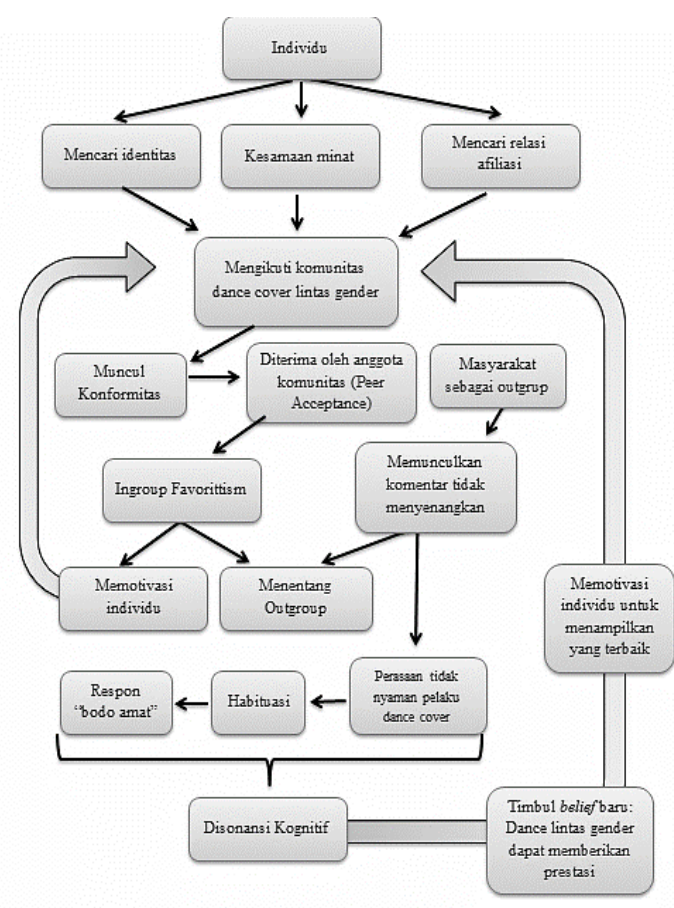

Gambar 1.Dinamika psikologis gabungan

\section{Simpulan dan Saran}

Simpulan

Alasan individu melakukan penampilan K-pop dance cover lintas gender terdiri dari beberapa aspek, yaitu: (1) aspek autonomi, (2) kompetensi, (3) keterkaitan atau afiliasi, (4) achievement atau pencapaian, dan (5) kebutuhuan akan rasa aman. Aspek-aspek ini membentuk dua dimensi motivasi yaitu motivasi internal berupa pencarian identitas diri dengan cara self-discovery dan mengikuti kelompok sebagai sumber identitas; dan motivasi eksternal berupa keinginan individu untuk bergabung dan memiliki relasi dekat dengan teman-teman yang memiliki minat yang sama pada K-pop dance cover lintas gender agar dapat diterima dengan teman sebayanya (Peer Acceptance) timbul perilaku konformitas dengan tujuan dapat membaur dengan sesama anggota komunitas. Keinginan individu untuk mencapai Mastery Goals yang telah ditetapkan individu juga menjadi faktor eksternal dari munculnya motivasi.
Diterimanya individu dalam suatu kelompok menimbulkan adanya ingroup favoritisism dimana sesama anggota kelompok dipandang eksklusif dan memilih mendukung kelompoknya sendiri dibanding kelompok lain, rasa ingroup yang kuat akan menimbulkan perselisihan dengan outgrup. Individu dalam kelompok K-pop dance cover lintas gender berkeyakinan bahwa dance cover lintas gender merupakan hal wajar karena merupakan bentuk hiburan seni dan wadah untuk menyalurkan bakat menari. Penggunaan atribut lintas gender bagi pelaku dimaksudkan untuk menunjang penampilan yang maksimal, selain itu responden wanita juga mengungkapkan penggunaan kostum idol pria membuat lebih nyaman dan merasa aman karena lebih tertutup dibandingkan kostum idol wanita.

\section{Saran}

Berdasarkan kesimpulan yang telah disebutkan sebelumnya, peneliti memberi beberapa rekomendasi saran.

1. Bagi pelaku dance cover

Bagi pelaku dance cover lintas gender sebaiknya memperhatikan kaidah dan aturan di masyarakat sehingga tidak terjadi selisih paham dan tercipta kerukunan. Pelaku dance cover juga perlu memperhatikan norma kesopanan dan tempat menyelenggarakan kompetisi di wilayah yang tidak terlalu konservatif dan plural sehingga pelaku tetap bisa menampilkan pertunjukannya dan masyarakat yang lebih beragam dapat menonton pertunjukan individu.

2. Bagi masyarakat

Setiap individu memiliki alasannya masing-masing dalam setiap perbuatan dan perilaku, tidak terkecuali pelaku dance cover lintas gender. Oleh karena itu masyarakat bisa mengapresiasi para pelaku dance cover. Kemudian jika terdapat perbedaan pendapat dapat disampaikan dengan cara yang halus 
agar menjadi kritik yang dapat membangun pelaku dance cover lintas gender.

\section{Daftar Pustaka}

Bench, S. W., Schlegel, R. J., Davis, W. E., \& Vess, M. (2015). Thinking about change in the self and others: The role of self-discovery metaphors and the true self. Social Cognition, 33(3), 169-185.

Fauzan, A. (2015). Memahami lintas gender dalam seni tari Didik Nini Towok. Diakses pada 18 Maret 2020 di laman berikut http://kabarkampus.com/2015/09/m emahami-lintas gender-dalam-senitari-didik-nini-towok/

Fitriana, I. (2018). Video acara dugaan LGBT di Mal Magelang viral, ini faktanya. Diakses pada tanggal 22 Desember 2019 di laman berikut https://regional.kompas.com/read/2 018/10/16/09211651/video-acaradugaan-lgbt-di-mal-magelang-viral-inifaktanya?page $=$ all.

Hardiyanto, S. (2018). Dikira menjurus LGBT, Acara K-Pop di Magelang dibubarkan. Diakses pada tanggal 22 Desember 2019 di laman berikut https://www.jawapos.com/jpgtoday/14/10/2018/dikira-menjuruslgbt-acara-k-pop-di-magelangdibubarkan/

Joni, I. D. A. M., \& Sutarmanto, H. (2017). Disonansi kognitif Gay terkait budaya patrilineal di Bali. Gadjah Mada Journal of Psychology (GamajoP), 3(1), 1-12.

Khiun, L. K. (2013). K-pop dance trackers and cover dancers: Global Cosmopolitanizationand Local Spatialization. In The Korean Wave: Korean Media Go Global, edited by Youna Kim, 181-198. New York: Routledge.

McLeod, S. A. (2018). Cognitive dissonance. Simply Psychology. Diakses pada tanggal 7 Januari 2021 di https://www.simplypsychology.org/c ognitive-dissonance.html

Meigalia, E. \& Putra, Y. S. (2019) Penari lintas gender dalam tradisi lisan Minangkabau; Ronggeang Pasaman. Jurnal Aksara, 31 (1). DOI: 10.29255/aksara.v31i1.331.51-64

Moreno, R. (2010). Educational Psychology. University of New Mexico.

Pangerang, A. M. (2015, Oktober 6). Indonesia Jadi Tuan Rumah ASEAN KPop Dance Cover 2015. Dapat diakses di https://yogyakarta.kompas.com/read /2015/10/06/181015910/Indonesia.J adi.Tuan.Rumah.ASEAN.KPop.Dance.Cover.2015.

Papalia, D. E., \& Feldman, R. D. (2014). Menyelami perkembangan manusia edisi 12 buku 1. Jakarta: Salemba Humanika.

PijarPsikologi. (2019). Perempuan, pola asuh anak dan budaya patriarki. Diakses pada 15 April $2020 \quad$ di https://pijarpsikologi.org/perempuan -pola-asuh-anak-dan-budaya-patriarki

Purwanta, H. (2015). Komunitas di Yogyakarta sebagai sarana aktualisasi diri. Jurnal Penelitian, 19(1).

Reeve, Jhonmarshall. (2009). Understanding motivation and emotion - 5th ed. New Jersey: John Wiley \& Sons, Inc.

Santrock, J. W. (2012). Liffe-span development (Edisi 13 Jilid 1). Jakarta: Erlangga.

Sarwono, W. S \& Meinarno, E. A. (2009). Psikologi sosial. Jakarta: Salemba Humanika

Smith, A., Jonathan, Flowers, P., \& Larkin, M. (2009). Interpretative phenomenological analysis theory, method and research. Singapore: SAGE Publications AsiaPacific Pte Ltd.

Stewart, C., J. dan William B. C., Jr. (2012). Interviu: prinsip dan praktik. Jakarta: Salemba Humanika. 
Sugiyono. (2016). Metode penelitian kuantitatif, kualitatif dan R\&D. Bandung: Alfabeta.

Sugoto, M. C., \& Cahyadi, J. (2009). Kajian iklan layanan masyarakat tentang pentingnya mengucapkan terima kasih bagi para remaja di Surabaya. Nirmana, 11(2), 106-113.

Sunardi, C. (2009). Pushing at the boundaries of the body: Cultural politics and cross-gender dance in East Java. Bijdragen tot de taal-, land-en volkenkunde/Journal of the Humanities and Social Sciences of Southeast Asia, 165(4), 459-492.

Yunengsih, P., Indrayuda, I., \& Asriati, A. (2018). Motivasi siswa laki-laki dalam mengikuti pengembangan diri Seni Tari di SMA Negeri 1 Batang Anai. Jurnal Sendratasik, 6(2), 48-54.

Zuriah, N. (2006). Metodologi penelitian sosial dan pendidikan: Teori dan aplikasi. Jakarta: Bumi Aksara. 